\title{
Meningkatkan Prestasi Belajar Ips Materi Aktivitas Ekonomi Yang Berkaitan Dengan Sumber Daya Alam Dan Potensi Didaerahnya Dengan Model Student Facilitator And Explaining Siswa Kelas IV Semester II SDN Karang Tengak Kec. Kopang Tahun Pelajaran 2018/2019
}

\author{
Zaeni \\ SDN Karang Tengak kecamatan Kopang
}

\begin{abstract}
Abstrak :Untuk membangkitkan semangat belajar maka dalam pelajaran IPS harus memilih metode yang tepat. Metode yang di pilih dalam pembelajaran harus metode dengan pendekatan yang berpusat pada siswa sehingga siswa merasa lebih terdorong untuk turut aktif dalam pembelajaran. Pendekatan Student facilitator and Explaining merupakan pendekatan dengan konsep dasar yang mewadahi, menginspirasi, menguatkan, dan melatari pemikiran tentang bagaimana metode pembelajaran diterapkan berdasarkan teori tertentu. Pada materi Pentingnya Koperasi dalam meningkatkan kesejahteraan yang di ajarkan di Kelas IV Sekolah Dasar Negeri Karang Tengak Kecamatan Kopang pendekatan Student facilitator and Explaining di rasa tepat sehingga akan di gunakan dalam penelitian ini sebagai cara untuk meningkatkan prestasi belajar siswa pada materi Pentingnya Koperasi dalam meningkatkan kesejahteraan . Permasalahan yang di angkat dalam PTK ini adalah Meningkatkan Semangat Belajar Siswa Dalam Pembelajaran Pentingnya Koperasi dalam meningkatkan kesejahteraan Melalui Pendekatan Student facilitator and Explaining di Kelas IV Sekolah Dasar Negeri Karang Tengak Kecamatan Kopang Tahun Ajaran 2018/2019. Hasil akhir dari penelitian ini adalah Dengan Pendekatan Student facilitator and Explaining yang telah dilaksanakan maka terdapat peningkatan Semangat Belajar Siswa Dalam Pembelajaran Pentingnya Koperasi dalam meningkatkan kesejahteraan pada siswa Kelas IV Sekolah Dasar Negeri Karang Tengak Kecamatan Kopang . Terbukti dari data hasil belajar pada siklus 1 nilai rata rata yang siswa mencapai 72,1 Dan hasil rata rata nilai siswa yang pada siklus 2 ini mencapai 77,5. Dapat di simpulkan bahwa penggunaan Pendekatan Student facilitator and Explaining dalam meningkatkan Prestasi Belajar Siswa Dalam Pembelajaran IPS materi Pentingnya Koperasi dalam meningkatkan kesejahteraan .
\end{abstract}

Kata Kunci : Prestasi Belajar "aktivitas ekonomi yang berkaitan dengan sumber daya alam dan potensi daerah,Pendekatan Student facilitator and Explaining

\section{PENDAHULUAN}

Kelangsungan dan keberhasilan proses belajar mengajar bukan hanya dipengaruhi oleh faktor intelektual saja, melainkan juga oleh faktor-faktor nonintelektual lain yang tidak kalah penting dalam menentukan hasil belajar seseorang, salah satunya adalah kemampuan seseorang siswa untuk meprestasi dirinya. Mengutip pendapat Daniel Goleman (2004: 44), kecerdasan intelektual (IQ) hanya menyumbang $20 \%$ bagi kesuksesan, sedangkan $80 \%$ adalah sumbangan faktor kekuatan-kekuatan lain, diantaranya adalah kecerdasan emosional atau Emotional Quotient (EQ) yakni kemampuan meprestasi diri sendiri, mengatasi frustasi, mengontrol desakan hati, mengatur suasana hati (mood), berempati serta kemampuan bekerja sama.

Semangat belajar sangat penting artinya dalam kegiatan belajar, sebab adanya semangat mendorong siswa meningkatkan prestasi belajar dan sebaliknya kurang adanya semangat akan melemahkan prestasi belajar. Semangat merupakan syarat mutlak dalam belajar; seorang siswa yang belajar tanpa semangat (atau kurang prestasi) tidak akan berhasil dengan maksimal.

Dalam implikasinya pada dunia belajar, siswa atau pelajar tidak akan terprestasi secara penuh dalam belajar. Termasuk dalam mata pelajaran IPS yang di rasa membosankan. Guru sebagai seorang pendidik harus tahu apa yang diinginkan oleh para siswanya. Seperti 
kebutuhan untuk berprestasi, karena setiap siswa memiliki kebutuhan untuk berprestasi yang berbeda satu sama lainnya. Tidak sedikit siswa yang memiliki semangat belajar yang rendah, mereka cenderung takut gagal dan tidak mau menanggung resiko dalam mencapai prestasi belajar yang tinggi. Meskipun banyak juga siswa yang memiliki semangat belajar yang tinggi. Siswa memiliki semangat belajar tinggi kalau keinginan untuk sukses benar-benar berasal dari dalam diri sendiri. Siswa akan bekerja keras baik dalam diri sendiri maupun dalam bersaing dengan siswa lain.

Untuk membangkitkan semangat tersebut, maka dalam pelajaran IPS harus memilih metode yang tepat. Metode yang di pilih dalam pembelajaran harus metode dengan pendekatan yang berpusat pada siswa sehingga siswa merasa lebih terdorong untuk turut aktif dalam pembelajaran.

Pendekatan Student facilitator and Explaining merupakan pendekatan dengan konsep dasar yang mewadahi, menginspirasi, menguatkan, dan melatari pemikiran tentang bagaimana metode pembelajaran diterapkan berdasarkan teori tertentu.

Pada materi aktivitas ekonomi yang berkaitan dengan sumber daya alam dan potensi daerah. yang di ajarkan di Kelas IV Sekolah Dasar Negeri Karang Tengak Kecamatan Kopang pendekatan Student facilitator and Explaining di rasa tepat sehingga akan di gunakan dalam penelitian ini sebagai cara untuk meningkatkan prestasi belajar siswa pada materi aktivitas ekonomi yang berkaitan dengan sumber daya alam dan potensi daerah.

Semangat dalam pengertian yang berkembang di masyarakat sering-kali disamakan dengan prestasi. Oleh karena itu untuk dapat memahami dan mempunyai gambaran yang luas, berikut ini diberikan beberapa pengertian prestasi antara lain Wlodkowski (dalam Suciati, 2001:52) menjelaskan prestasi sebagai suatu kondisi yang menyebabkan atau menimbulkan perilaku tertentu, serta yang memberi arah dan ketahanan (persistence) pada tingkah laku tersebut.
Pendekatan adalah konsep dasar yang mewadahi, menginspirasi, menguatkan, dan melatari pemikiran tentang bagaimana metode pembelajaran diterapkan berdasarkan teori tertentu. Oleh karena itu banyak pandangan yang menyatakan bahwa pendekatan sama artinya dengan metode. Pendekatan ilmiah berarti konsep dasar yang menginspirasi atau melatarbelakangi perumusan metode mengajar dengan menerapkan karakteristik yang ilmiah. Pendekatan pembelajaran ilmiah (Student facilitator and Explaining teaching) merupakan bagian dari pendekatan pedagogis pada pelaksanaan pembelajaran dalam kelas yang melandasi penerapan metode ilmiah. Penerapan pendekatan saintifik dalam pembelajaran harus memenuhi tiga prinsip utama, yaitu: (1) Belajar siswa aktif, dalam hal ini termasuk inquiry-based learning atau belajar berbasis penelitian, cooperative learning atau belajar berkelompok, dan belajar berpusat pada siswa, (2) Assessment berarti pengukuran kemajuan belajar siswa yang dibandingkan dengan targepencapaian tujuan belajar. (3) Keberagaman mengandung makna bahwa dalam pendekatan ilmiah mengembangkan pendekatan keragaman. Pendekatan ini membawa konsekuensi siswa unik, kelompok siswa unik, termasuk keunikan dari kompetensi, materi, instruktur, pendekatan dan metode mengajar, serta konteks.

\section{METODE PENELITIAN}

Adapun rancangan yang digunakan dalam penelitian ini adalah menggunakan Penelitian Tindakan Kelas (Classromm Activity Research). Pelaksanaan tindakan dalam PTK meliputi empat alur (langkah): (1) perencanaan tindakan; (2) pelaksanaan tindakan; (3) Pengamatan; (4) refleksi.

Alur (langkah) pelaksanaan tindakan yang dimaksud dapat dilihat pada gambar berikut. Sebelum melaksanakan tindakan, terlebih dahulu peneliti merencanakan secara seksama jenis tindakan yang akan dilakukan. Kedua, setelah rencana disusun secara matang, barulah tindakan itu dilakukan. Ketiga, bersamaan dengan dilaksanakan tindakan, peneliti mengamati proses pelaksanaan tindakan itu sendiri dan akibat yang ditimbulkannya. Keempat, berdasarkan 
hasil pengamatan tersebut, peneliti kemudian melakukan refleksi atas tindakan yang telah dilakukan. Jika hasil refleksi menunjukkan perlunya dilakukan perbaikan atas tindakan yang telah dilakukan., maka rencana tindakan perlu disempurnakan lagi agar tindakan yang dilaksanakan berikutnya tidak sekedar mengulang apa yang telah diperbuat sebelumnya. Demikian seterusnya sampai masalah yang diteliti dapat mengalami kemajuan.

Adapun rancangan penelitian tindakan kelas ini dilakukan dalam II siklus. Dengan catatan: Apabila siklus I berhasil sesuai kriteria yang diinginkan, maka tetap dilakukan siklus II untuk pemantapan, tetapi kalau siklus I tidak berhasil, maka dilakukan siklus II dengan cara menyederhanakan materi dan menambah media pembelajaran. Apabila pada siklus II belum terjadi peningkatan, maka siklus III harus dipersiapkan untuk mengatasi kesulitan yang dialami siswa.

\section{HASIL PENELITIAN DAN PEMBAHASAN}

Hasil Penelitian

\section{Pra Siklus}

Pada kegiatan observasi awal bertujuan untuk mengetahui kondisi semangat siswa mengikuti pelajaran Pentingnya Koperasi dalam meningkatkan kesejahteraan

Kemudian dari hasil tindakan pra siklus serta pengamatan langsung dalam kegiatan pembelajaran menunjukkan bahwa siswa belum mampu mengerjakan soal dengan benar dan menunjukkan sikap yang kurang semangat dalam belajar. Hal ini didukung pula dengan perolehan hasil belajar aktivitas ekonomi yang berkaitan dengan sumber daya alam dan potensi daerah pada kegiatan pra siklus yang belum mencapai standart KKM yang telah ditentukan oleh sekolah yaitu skor 70 untuk mata pelajaran IPS . Berdasarkan hasil dari kegiatan pra siklus diatas diperoleh kesimpulan bahwa pembelajaran yang bersifat konvensional dengan menggunakan ceramah dan pemberian tugas kurang mampu meningkatkan semangat siswa mengikuti pelajaran Pentingnya Koperasi dalam meningkatkan kesejahteraan .

\section{Siklus 1}

pada siklus ke I adalah meskipun masih terdapat beberapa kesulitan yang dihadapi oleh siswa dalam pembelajaran aktivitas ekonomi yang berkaitan dengan sumber daya alam dan potensi daerah, akan tetapi penerapan pendekatan Student facilitator and Explaining pada siklus I ini berjalan dengan cukup baik. Hal ini terlihat pada data hasil belajar Siswa dalam Mengikuti aktivitas ekonomi yang berkaitan dengan sumber daya alam dan potensi daerah pada siklus 1 yang rata-rata siswa sudah mencapai nilai KKM dan menunjukan adanya peningkatan nilai hasil belajar dari pra siklus.

\section{Siklus 2}

Penerapan pendekatan Student facilitator and Explaining banyak menuntut peran aktif siswa karena pendekatan ini adalah pendekatan pembelajaran yang berorientasi pada siswa. Hal ini dibuktikan dengan perolehan hasil belajar siswa yang mengalami peningkatan dimulai dari pelaksanaan pra siklus sampai pada siklus II. Hasil perolehan nilai siswa menunjukan adanya peningkatan nilai hasil belajar dari siklus-siklus sebelumnya. Dapat di simpulkan bahwa ada peningkatan hasil belajar siswa dari pra siklus hingga siklus II. Terbukti bahwa jumlah siswa yang tuntas mengalami peningkatan, dan jumlah siswa yang belum tuntas mengalami penurunan. 


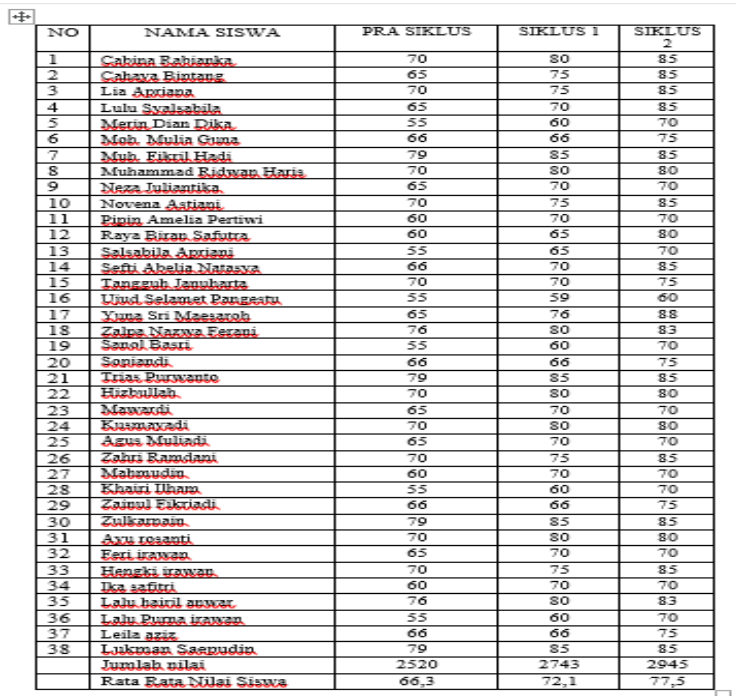

Tabel ;4.4 Semangat Siswa Mengikuti Pelajaran IPS"

Satuan Pendidikan : SD Karang Tengak

Kelas/Semester : VI /2

Mata Pelajaran : IPS

Materi Pokok : Pentingnya Koperasi dalam meningkatkan kesejahteraan

\begin{tabular}{|c|c|c|c|c|c|}
\hline \multirow[t]{2}{*}{ No. } & \multirow[t]{2}{*}{ Aspelk yang diobservasit } & \multicolumn{4}{|c|}{ Bilibang } \\
\hline & & 1 & 2 & 3 & 4 \\
\hline 1 & Interaksi antar sisvar dalam kontelks pembelajaran. & & $v$ & & \\
\hline 2 & Interaksoi siswa dengan guru. & & $v$ & & \\
\hline 3 & Kosungeuhan dalam mengerjakan tugas kelompok & & & $v$ & \\
\hline 4 & Pembagian tugas kelompolk olech siswa dengan baik & & $v$ & & \\
\hline 5 & Penzaldlasn kegiatan belajiar olech siswata. & & $v$ & & \\
\hline 6 & Kerjasama yang baik antar siswa dalam belajar & & & $v$ & \\
\hline 7 & Kemandirian siswa dalam belajas. & & & $v$ & \\
\hline 8 & siava, menghargai pendapats orang lain. & & $v$ & & \\
\hline 9 & sisqua mengkritik orang lain dengan baik & & & V & \\
\hline 10 & sisura menghargai pendapat yang berbeda. & & & $v$ & \\
\hline
\end{tabular}

Keterangan:

1 : Tidak ada

2: Jarang

3: Cukup banyak

4: Banyak

Tabel 4.5. Hasil Observasi Siklus 2

Satuan Pendidikan : SDN Karang Tengak

Kelas/Semester : VI /2

Mata Pelajaran : IPS

Materi Pokok : Pentingnya Koperasi

dalam meningkatkan kesejahteraan

\begin{tabular}{|c|c|c|c|c|}
\hline \multirow[t]{2}{*}{ No. } & \multirow[t]{2}{*}{ Aspek yang diohserscasti } & \multicolumn{3}{|c|}{ Dilikan } \\
\hline & & & & 4 \\
\hline 1 & Interakgo antar siswra dalam konteks pembelajaran. & & & $v$ \\
\hline 2 & 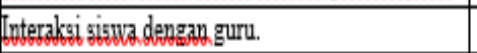 & & & $\mathrm{v}$ \\
\hline 3 & 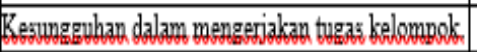 & & & $\mathrm{v}$ \\
\hline 4 & Tembagian tugas kelompols oleh sigura denzan bails & & $v \mid$ & \\
\hline 5 & Pengelolanan kegiatan belajar oleh siawa. & & $v \mid$ & \\
\hline 6 & 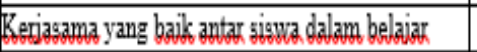 & & & $v$ \\
\hline 7 & Kemandirian siswa dalam belajar. & & & $\mathrm{v}$ \\
\hline 8 & siswa menghargai pendanat orang lain. & & & $\mathrm{v}$ \\
\hline 9 & siswa mengkritik orang lain dengam baik & & & $v$ \\
\hline 10 & Liswa menghargai pendapat yang berbeda. & & & $\mathrm{v}$ \\
\hline
\end{tabular}

Keterangan:

1 : Tidak ada

2: Jarang

3: Cukup banyak

4: Banyak

\section{Pembahasan}

\section{Pembahasan Siklus Pertama}

Pada proses pelaksanaan siklus ke-1 siswa diminta untuk mempelajari Pentingnya Koperasi dalam meningkatkan kesejahteraan dalam IPS melalui pendekatan Student facilitator and Explaining . Dengan pendekatan Student facilitator and Explaining yang berpusat pada siswa maka siswa lebih tertarik dan bersemangat dalam melaksanakan proses pembelajaran. Dengan pendekatan pembelajaran yang telah dilaksanakan maka terdapat peningkatan Semangat Siswa Mengikuti Pelajaran IPS Materi aktivitas ekonomi yang berkaitan dengan sumber daya alam dan potensi daerah. Terbukti pula dari data hasil belajar pada siklus 1 nilai rata rata yang siswa mencapai 72,1. Hasil observasi pada siklus 1 ini meskipun masih ada beberapa siswa yang tidak semnagat dalam pembelajaran. Tetapi pembelajaran pada siklus 1 ini berjalan lancar. Hal tersebut menunjukan adanya peningkatan Semangat Siswa Mengikuti Pelajaran IPS Materi aktivitas ekonomi yang berkaitan dengan sumber daya alam dan potensi daerah di bandingkan dengan pra siklus.

2. Pembahasan Siklus Kedua

Pada siklus ke II ini terdiri dari kegiatan perencanaan, pengamatan, dan refleksi tindakan.Pada siklus ini 
pelaksanaan pembelajaran dengan pendekatan Student facilitator and Explaining juga sama seperti yang di terapkan pada siklus I, dan hasil dari metode penelitian yang sudah di laksanakan menunjukkan peningkatan Semangat Siswa Mengikuti Pelajaran IPS Materi aktivitas ekonomi yang berkaitan dengan sumber daya alam dan potensi daerah. Hal tersebut dapat di lihat dari hasil rata rata nilai siswa yang pada siklus 2 ini mencapai 77,5. Dan pada hasil observasi sudah banyak siswa yang melakukan aktifitas dan kegiatan yang menunjukkan adanya semangat belajar dalam pembelajaran.

\section{KESIMPULAN}

Kesimpulan dari penelitian ini adalah

1. Pada siklus 1 setelah menggunakan pendekatan Student facilitator and Explaining dalam pembelajaran maka terlihat adanya semangat siswa dalam mengikuti IPS Materi aktivitas ekonomi yang berkaitan dengan sumber daya alam dan potensi daerah Pada siklus 1 setelah menggunakan pendekatan Student facilitator and Explaining dalam pembelajaran maka terlihat peningkatan hasil belajar siswa dengan rata rata nilai siswa pada siklus 1 adalah 72,1. Lebih besar dari pra siklus yang memperoleh rata rata hanya 66.3.

2. Pada siklus 2 setelah menggunakan pendekatan Student facilitator and Explaining dalam pembelajaran maka terlihat adanya peningkatan semangat siswa dalam mengikuti pelajaran IPS Materi aktivitas ekonomi yang berkaitan dengan sumber daya alam dan potensi daerah.

3. Pada siklus 2 setelah menggunakan pendekatan Student facilitator and Explaining dalam pembelajaran maka terlihat peningkatan hasil belajar siswa dengan rata rata nilai siswa pada siklus 2 adalah 77,5. Lebih besar dari pra siklus yang memperoleh rata rata hanya 66.3, dan lebih besar dari siklus 1 yang memperoleh rata rata 72,1 .
4. Dapat di simpulkan bahwa penggunaan pendekatan Student facilitator and Explaining dalam meningkatkan semangat siswa mengikuti pelajaran IPS Materi aktivitas ekonomi yang berkaitan dengan sumber daya alam dan potensi daerah di Kelas IV Sekolah Dasar Negeri Karang Tengak Kecamatan Kopang Tahun Ajaran 2015 /2016 tepat sasaran.

\section{DAFTAR PUSTAKA}

Ahmadi, Abu dan Widodo Supriyono. 1991. Psikologi Belajar. Jakarta: Rineka Cipta.

Ahmad Rohani. (1997). Media Instruksional Edukatif. Jakarta: Rineka Cipta

Arief S. Sadiman, dkk. (2006). Media Pendidikan, Pengertian, Pengembangan, dan Pemanfaatannya. Jakarta: Pustekkom. Dikbud. dan PT. Raja Grafindo Persada

Darmansyah. 2006. Penelitian Tindakan Kelas. UNP

Depdiknas. 2004. Pedoman Penulisan Karya Ilmiah. Cetakan Eisi ke empat Malang Pers.

Goleman, Daniel, Emitional Intelligence Kecerdasan Emosional Mengapa EQ Lebih Penting Daripada IQ, Jakata: PT Gramedia Pustaka Utama, 2004.

Hamalik, Oemar. 2002. Proses Belajar Mengajar. Jakarta: Bumi Asara.

Ivor. K.Davies. 1991. Pengelolaan Belajar. Jakarta CV Rajawali

Nana Sujana. 1989. Teori-teori belajar Untuk pengajaran. Bandung

Ngalim Purwanto, Psikologi Pendidikan, Bandung: PT. Remaja Rosdakarya, 2002

RosdaSardiman. 2006. Interaksi dan Prestasi Belajar Mengajar. Jakarta: Raja Grafindo Persada

Sugandi, Achmad. 2004. Teori Pembelajaran. Semarang: IKIP Semarang Press.

Slameto. 1995. Belajar Dan Faktor-Faktor Yang Mempengaruhi. Jakarta: Rineka Cipta. Sudjana, Nana. 2001. Penilaian Hasil Proses Belajar Mengajar. Bandung: Remaja Rosdakarya. 
Syah, Muhibbin. 2006. Psikologi Belajar. Jakarta: PT Raja Grafindo Persada.

Tabrani Rusyan, Pendekatan dalam Proses Belajar Mengajar, Bandung: PT. Remaja Rosdakarya, 2001.

Tim Penyusun KBBI. 2007. Kamus Besar Bahasa Indonesia (edisi ketiga). Jakarta: Balai Pustaka.

Tim Penyusun Kamus Pembinaan dan Pengembangan Bahasa. (2005). Kamus Besar Bahasa Indonesia. Jakarta: Balai Pustaka

Wina Sanjaya. 2006. Strategi Pembelajaran. Jakarta. Kencana Wiradikromo Sartono. 2003. Dimensi Tiga. Jakarta. Erlangga

Zainal Abidin. 2004. Evaluasi Pengajaran. Padang. UNP 